\title{
ANTENATAL CARE PRACTICES IN RANGELI VDC OF MORANG DISTRICT, NEPAL
}

\author{
Sah RB ${ }^{1}$, Subedi L ${ }^{2}$, Shah $\mathrm{U}^{3}$, Jha $\mathrm{N}^{4}$, Pokharel $\mathrm{PK}^{5}$
}

\section{ABSTRACT}

INTRODUCTION: Nepal has one of the worst maternal and perinatal morbidity and mortality due to the lack of antenatal care (ANC) practices of pregnant women. The objective of this study was to find out the ANC practices and to find out the association between sociodemographic characteristics and antenatal care visits.

MATERIALAND METHODS: The cross-sectional study was conducted from $1^{\text {st }}$ March to $14^{\text {th }}$ March, 2014 among the residents of Rangeli VDC of Morang District in Eastern Nepal where 300 households were taken as subjects. Simple random sampling technique was applied for data collection. Semi-structured questionnaire was used and face to face interview was conducted. Chi-square test was applied to find out the association between sociodemographic characteristics and antenatal care visits.

RESULTS: Almost fifty five percent of respondents attended ANC visits. The findings revealed that about $55 \%$ received iron, calcium and folic acid tablets and almost $61 \%$ of the pregnant women took the tetanus toxoid (TT) injections among who attended ANC. Almost 54.6\% of pregnant Hindu women have completed four ANC visits. Women with School Leaving Certificate (SLC) and higher education level was more likely to ANC visits (100\%) than women with below SLC $(73 \%)$ and no education $(25 \%)$. Furthermore, education of husband shows stronger association with ANC visits $(\mathrm{P}<0.001)$.

CONCLUSION: The problem of ANC practices is common and has become a key public health concern for all. Lack of education and poor occupation of wife and husband led some of the respondents not to attend the recommended ANC visits.

KEYWORDS: Pregnancy, Antenatal Care, ANC

1. Associate Professor, School of Public Health and Community Medicine, BP. Koirala Institute of Health Sciences, Dharan, Nepal

2. Senior Instructor, School of Public Health and Community Medicine, BPKIHS, Dharan

3. MSc. Student, Department of Microbiology, Sunsari Technical College PVT. LTD, Dharan

4. Professor, School of Public Health and Community Medicine, BPKIHS, Dharan, Nepal

5 Professor \& Chief, School of Public Health and Community Medicine, BPKIHS, Dharan, Nepal

For Correspondence

Dr. Ram Bilakshan Sah

Associate Professor,

School of Public Health \& Community Medicine

B P Koirala Institute of Health Sciences, Dharan, Nepal

E-mail: bilaksah@Yahoo.com 


\section{INTRODUCTION}

The potential of antenatal care for reducing maternal morbidity and improving newborn survival has been widely acknowledged. ${ }^{1}$ A multi-country randomised controlled trial led by WHO showed that essential interventions can be provided over four visits at specified intervals, at least for healthy women with no underlying medical problems. ${ }^{2}$ However surveys had shown countries like Bangladesh, Ethiopia, Morocco, Nepal and Yemen have relatively high percentages of women who received only one antenatal visit. ${ }^{3}$ Globally, one third of births take place at home without the assistance of a skilled attendant.

The risk assessment and classification of pregnant women into low risk and high risk groups has remained an integral component of most antenatal policies. Such antenatal policies ensure access to higher levels of care for at-risk pregnancies based on need. ${ }^{5}$ In South East Asian Region, ANC coverage in Sri Lanka is $99 \%$ and $44 \%$ in Nepal, and Maternal Mortality Rate (MMR) is lowest in Sri Lanka (23/100,000 live birth) and highest in Nepal (539/100,000 live birth), all of which can be linked. ${ }^{6}$

Antenatal care focuses on maintaining maternal and fetal wellbeing throughout pregnancy and child birth. ${ }^{7}$ Some studies have demonstrated significant differences in maternal and perinatal morbidity and mortality rates between pregnant women who utilized modern antenatal care and those who did not. ${ }^{8,9}$ Therefore, this study was conducted to find out the antenatal care practices and to find out the association between sociodemographic characteristics and antenatal care practices among residents of Rangeli VDC of Morang District.

\section{MATERIAL AND METHODS}

The cross-sectional study was conducted from $1^{\text {st }}$ March to $14^{\text {th }}$ March, 2014 among the residents of Rangeli VDC of Morang District in Eastern Nepal. The baseline survey revealed that the women for 58.9\% ANC visits (Oyibo PG et al in Nigeria in $2011)^{10}$, more than that $(78.9 \%$ ) of women (Sanjel S in Nepal in 2011), ${ }^{11}$ and highest in Dhankuta, Nepal (82.4\%) (Sah RB in Dhankuta, Nepal in 2013) $)^{12}$. So taking lower value $58.9 \%$ of women completed four ANC visits, sample size was calculated at $95 \%$ CI \& 90\% powers then it become 300 women. All the participants aged 15 to 45 years from the selected households were included in the study. There are 9 wards in Rangeli VDC. Among 9 wards, the ward number 1, 2, 3 and 4 which have almost equal proportion of population was randomly selected by lottery method. The list of households of these 4 wards was prepared and equal number of households (75) from each ward was selected on the basis of simple random sampling.

Semistructured questionnaire was applied to the study subjects in the presence of investigator and face to face interview was conducted. A written permission was taken from concerned authority and an informed verbal consent was taken from the participants of the study. Those families which were available after three visits of follow up in the study and willing to give verbal consent were included in the study.

The collected data was entered in MS Excel 2000. The analysis was done by using statistical software SPSS (Statistical Package for Social Science) 17.0 version. Chi-square test was applied to find out the association between sociodemographic characteristics and ANC visits. The probability of occurrence by chance is significant if $\mathrm{P}<0.05$ with $95 \%$ confidence interval.

\section{RESULTS}

Table 1: ANC practices $(\mathbf{N}=\mathbf{3 0 0})$

\begin{tabular}{|c|c|c|}
\hline Characteristics & Frequency & Percent \\
\hline $\begin{array}{c}\text { ANC visit } \\
\text { Yes } \\
\text { No }\end{array}$ & $\begin{array}{l}165 \\
135 \\
\end{array}$ & $\begin{array}{l}55.0 \\
45.0 \\
\end{array}$ \\
\hline $\begin{array}{l}\text { If ANC visits done, then how many visits } \\
\quad<4 \\
=4\end{array}$ & $\begin{array}{l}165 \\
135\end{array}$ & $\begin{array}{l}55.0 \\
45.0\end{array}$ \\
\hline $\begin{array}{l}\text { Iron, calcium andfolic acid taken during pregnancy } \\
\text { Yes } \\
\text { No }\end{array}$ & $\begin{array}{l}165 \\
135\end{array}$ & $\begin{array}{l}55.0 \\
45.0\end{array}$ \\
\hline $\begin{array}{l}\text { TT vaccine taken during pregnancy } \\
\text { Yes } \\
\text { No }\end{array}$ & & $\begin{array}{l}61.0 \\
39.0\end{array}$ \\
\hline $\begin{array}{l}\text { If iron, calcium andfolic acid taken, then when }(\mathrm{n}=165) \\
\text { Before pregnancy } \\
\text { During pregnancy }\end{array}$ & $\begin{array}{c}10 \\
155\end{array}$ & $\begin{array}{c}6.1 \\
93.9\end{array}$ \\
\hline $\begin{array}{l}\text { If no ANC visits, why }(\mathrm{n}=135) \\
\text { Lack of knowledge } \\
\text { Distant health care centre } \\
\text { Family rejection }\end{array}$ & $\begin{array}{l}103 \\
20 \\
12\end{array}$ & $\begin{array}{l}76.3 \\
14.8 \\
8.9\end{array}$ \\
\hline $\begin{array}{l}\text { If iron, calcium andfolic acid not taken, then why }(\mathrm{n}=135) \\
\text { Lack of knowledge } \\
\text { Disbelief } \\
\text { Distant health facility } \\
\text { Others (Family rejection, lack of } \\
\quad \text { Money) }\end{array}$ & $\begin{array}{c}117 \\
10 \\
5 \\
3\end{array}$ & $\begin{array}{l}86.7 \\
7.4 \\
3.7 \\
2.2\end{array}$ \\
\hline $\begin{array}{l}\text { TT vaccine not taken during pregnancy, why }(\mathrm{n}=117) \\
\text { Lack of knowledge } \\
\text { Difficult reach to health centre } \\
\text { Disbelief }\end{array}$ & $\begin{array}{c}102 \\
4 \\
11\end{array}$ & $\begin{array}{l}87.2 \\
3.4 \\
9.4\end{array}$ \\
\hline
\end{tabular}

Table 1 shows that fifty five percent of pregnant women attended ANC visits. Almost fifty five percent of respondents 
received iron, calcium and folic acid tablets and about sixty one percent of the pregnant women took the tetanus toxoid (TT) injections.

Table 2: Association between socio-demographic variables and $A N C$ practices

\begin{tabular}{|l|c|c|c|c|}
\hline \multicolumn{1}{|c|}{ Characteristics } & \multicolumn{2}{|c|}{ ANC visit } & Total & P- value \\
\hline Religion & & & \\
$\quad$ Hindu & $160(54.6)$ & $133(45.4)$ & 293 & 0.377 \\
Others (Muslim, Christian) & $5(71.4)$ & $2(28.6)$ & 7 & \\
\hline Ethnicity & & & & \\
Brahmin/ Chhetri & $34(97.1)$ & $1(2.9)$ & 35 & $<0.001$ \\
Kirati & $2(100.0)$ & $0(0.0)$ & 2 & \\
Janajati & $67(45.6)$ & $80(54.4)$ & 147 & \\
Dalit & $2(18.2)$ & $9(81.8)$ & 11 & \\
Terai caste & $60(57.1)$ & $45(42.9)$ & 105 & \\
\hline Education of wife & & & & \\
Illiterate & $36(25.0)$ & $108(75.0)$ & 144 & $<0.001$ \\
Below SLC & $73(73.0)$ & $27(27.0)$ & 100 & \\
SLC and above & $56(100.0)$ & $0(0.0)$ & 56 & \\
\hline Education of husband & & & & \\
Illiterate & $5(6.9)$ & $67(93.1)$ & 72 & $<0.001$ \\
Below SLC & $67(49.6)$ & $68(50.4)$ & 135 & \\
SLC and above & $93(100.0)$ & $0(0.0)$ & 93 & \\
\hline Occupation of wife & & & & \\
Service & $11(100.0)$ & $0(0.0)$ & 11 & 0.011 \\
Business & $7(58.3)$ & $5(41.7)$ & 12 & \\
Farmer & $2(28.6)$ & $5(71.4)$ & 7 & \\
Housewife & $145(53.7)$ & $125(46.3)$ & 270 & \\
\hline Occupation of husband & & & & \\
Service & $39(97.5)$ & $1(2.5)$ & 40 & $<0.001$ \\
Business & $82(63.1)$ & $48(36.9)$ & 130 & \\
Farmer & $19(32.8)$ & $39(67.2)$ & 58 & \\
Others(Abroad,labor, & $25(34.7)$ & $47(65.3)$ & 72 & \\
$\quad$ unemployed) & & & & \\
\hline Total & $\mathbf{1 6 5 ( 5 5 . 0 )}$ & $\mathbf{1 3 5 ( 4 5 . 0 )}$ & $\mathbf{3 0 0}$ & \\
\hline
\end{tabular}

Table 2 shows that women with Brahmin/ Chhetri are more likely to have ANC visits compared to women of other rethnic groups.The relationship between ANC visits and the highest education level of women and husband shows that the utilization of ANC visits increases as education level increases. Furthermore, occupation of husband also shows stronger association with $\mathrm{ANC}$ visits $(\mathrm{p}<0.001)$.

\section{DISCUSSION}

Poor antenatal care is an important risk factor for adverse pregnancy outcomes among women. ${ }^{3}$ This study aimed to examine the antenatal care practices among mothers of reproductive age group in Rangeli VDCs of Morang. In current study, the ANC visits were made by $55 \%$ of women which was lower than study conducted by Sanjel $\mathrm{S}$ et al. in Nepal (61.4\%) of women, "Sah RB et al. in Dhankuta Municipality, Nepal $(82.4 \%)^{12}$, and Pradhan A in Nepal
$(62 \%)^{13}$. Similar result was seen in study from Uganda where majority of the women $(96 \%)$ had attended ANC in the pregnancy. ${ }^{14}$ A study conducted by Pradhan PMS et al. in Village Development Committees of Ilam District, NepaI showed the proportion of mothers completing the recommended four visits dropped to $69.5 \%$. This occurred despite majority of the participants residing within thirtyminute distance from the nearest health facility $(92 \%){ }^{15}$ Our study showed $45 \%$ of women did not attend antenatal services. It was due to lack of knowledge, distant health care centre and family rejection.

This study showed almost 55\% of women have taken Iron, calcium and folic acid tablets which is lower than a study conducted by Sanjel S et al. in hilly area of central Nepal showed that $95 \%$ of women have taken iron, calcium and folic acid tablet. ${ }^{11}$ Another study conducted by Sah RB in Dhankuta, Nepal showed majority of women $(81.7 \%)$ have taken the iron, calcium and folic acid tablet which is also higher than this study. ${ }^{12}$ Almost $45 \%$ of women did not taken iron, calcium and folic acid tablet. It was due to lack of knowledge, disbelief, distant health facility, family rejection and lack of money.

Almost sixty one percent of the pregnant women took the tetanus toxoid (TT) injections which is lower than the study conducted by Sanjel S et al. in Central Nepal (98\%) of women took tetanus toxoid (TT) vaccine ${ }^{11}$, Sah RB et al in Dhankuta Municipality where almost eighty three percent of the pregnant women took the tetanus toxoid (TT) injections ${ }^{12}$ and Pradhan A in Nepal (72\%) ${ }^{13}$. The coverage of TT vaccine was high with $94.4 \%$ of the pregnant women completed two doses. ${ }^{15}$ Our findings regarding TT injections is almost similar as the study conducted by Devkota B et al. in Nepal was $63 \% .{ }^{16}$

This study showed that attendance of ANC visits among the women with Hindu was lower (54.6\%) than those study conducted by Sah RB et al in Dhankuta, Nepal $(91.2 \%){ }^{12}$ This study showed that attendance of ANC visits among the women with Brahmin/ Chhetri was higher (97.1\%) than those study conducted by Sah RB et al. in Dhankuta, Nepal $(90.6 \%){ }^{12}$

This study showed that attendance of ANC visits among the women with SLC and above was higher (100\%) than those below SLC (73\%) and illiterate (25\%). Several studies have found a strong association between education and utilization of antenatal services. ${ }^{12,17}$ It was observed that the percentage of non educated pregnant women that received ANC was $17.2 \%$ while in educated pregnant women was $45.2 \%{ }^{16}$ The result from this study also supports the positive association between the education and utilization of ANC visits. It may be due to the women with higher education might have an enhanced 
knowledge of modern health care services.

Our study had a few limitations. Short duration and a small sample size restricted the generalizability of our findings. The causality behind absence of ANC visit could not be established owing to the study design being cross sectional.

\section{CONCLUSION}

We conclude that the problem of ANC practices is common and has become a key public health concern for all. Lack of education and poor occupation of wife and husband led some of the respondents not to attend the recommended ANC visits. Counseling sessions could be integrated during ANC visits. Therefore, increased attention is needed to ensure less educated and poor occupation, obtain better access to antenatal services. Programs to improve birth outcome should include promotion of maternal literacy, and early and regular antenatal checkup.

\section{ACKNOWLEDGEMENT}

We would like to thank to School of Public Health and Community Medicine for approval of our research work. We would like to acknowledge the $6^{\text {th }}$ semester students of MBBS Batch of 2011 who helped us during the study period and participants of Rangeli VDC.

\section{REFERENCES}

1. Gross K, Schellenberg JA, Kessy F, Pfeiffer C, Obrist B. Antenatal care in practice: an exploratory study in antenatal care clinics in the Kilombero Valley, south-eastern Tanzania. BMC Pregnancy and Childbirth 2011; 11:36. http://dx.doi.org/10.1186/1471-2393-11-36

2. Lincetto $O$, Mothebesoane-Anoh S, Gomez P, Munjanja S. Antenatal Care. Available from:http://www.who.int/pmnch/ media/publications/aonsectionIII_2.pdf. Accessed May 28, 2014.

3. Antenatal care in developing countries: promises, achievements and missed opportunities: an analysis of trends, levels and differentials,. WHO; UNICEF: 1990-2001.

4. Wanjira C, Mwangi M, Mathenge E, Mbugua G, $N^{\prime}$ 'ang'a Z . Delivery Practices and Associated Factors among Mothers Seeking Child Welfare Services in Selected Health Facilities in Nyandarua South District, Kenya. BMC Public Health 2011; 11:360.

http://dx.doi.org/10.1186/1471-2458-11-360

5. Rao KB, Harrison KA, Bergstrom S. Maternity Care in Developing Countries. London: RCOG press; 2001.
Organisation of maternity care in developing countries; pp. 2126.

6. Care Concern. A Quarterly Publication to Support Hope Foundation for Women \& Children of Bangladesh 2004; 2:3.

7. UNDP/UNFPA/WHO/World Bank Special Programme of Research Development and Research Training in Human Reproduction. Geneva: Department of Reproductive Health and Research, Family and Community Health, World Health Organization; 2002. WHO Antenatal Care Randomized Trial: Manual for Implementation of the New Model.

8. Carroli G, Rooney C, Villar J. How effective is antenatal care in preventing maternal mortality and serious morbidity? An overview of the evidence. Paediatr Perinat Epidemiol 2001; 15 (1):1-42. http://dx.doi.org/10.1046/j.1365-3016.2001.00001.x

9. Umeora OUJ, Ejikeme BN. Clinical correlates and trends in hospital maternal mortality rates in rural Nigeria. J Obstet Gynaecol 2006; 26(2):139-40. http://dx.doi.org/10.1080/01443610500443451

10. Oyibo PG, Ebeigbe PN, Nwonwu EU. Assessment of the risk status of pregnant women presenting for antenatal care in a rural health facility in Ebonyi State, South Eastern Nigeria. $N$ Am JMed Sci 2011; 3 (9):424-27.

http://dx.doi.org/10.4297/najms.2011.3424

11. Sanjel S, Ghimire RH, Pun K. Antenatal care practices in Tamang community of hilly area in central Nepal. Kathmandu Univ Med J 2011; 34 (2): 57-61.

12. Sah RB, K Gaurav, DD Baral, N Jha and PK Pokharel. Antenatal care practices in hilly area of Eastern region of Nepal. Journal of Chitwan Medical College 2013; 3 (4): 12-15.

13. Pradhan A. Situation of antenatal care and delivery practices. Kathmandu Univ Med J2005; 3 (3):260-70.

14. Tann CJ, Kizza M, Morison L. Use of antenatal services and delivery care in Entebbe, Uganda: a community survey. BMC Pregnancy and Childbirth 2007; 7:23. doi:10.1186/1471-23937-23. http://dx.doi.org/10.1186/1471-2393-7-23

15. Pradhan PMS, Bhattarai S, Paudel IS, Gaurav K, Pokharel PK. Factors Contributing to Antenatal Care and Delivery Practices in Village Development Committees of Ilam District, Nepal. Kathmandu Univ Med J2013; 41(1):60-65.

16. Devkota B. A study of knowledge Attitude and Practices of mother and Maternal and Child Health Care at Pandurung Village 1994. Unpublished Masters Thesis, Faculty of Education, T.U., Kirtipur, Nepal.

17. Becker S, Peters DH, Gray RH, Gultiano C, Blake RE. The determinant of use of maternal child health services in Metro Cebu, the Philippines, Health transition review 1993; 3: 77-89. 